\title{
Hepatic cirrhosis: A clinico-pathological review of 520 cases
}

\author{
R. N. M. MacSWEEN AND A. R. SCOTT ${ }^{1}$ \\ From the University of Glasgow, Department of Pathology, Western Infirmary, Glasgow
}

SYNOPSIS A clinico-pathological review of 520 patients with hepatic cirrhosis coming to necropsy at the Western Infirmary, Glasgow over the period 1900-69 is reported. There has been an overalli increase in incidence of cirrhosis since the 1940s, and this has been largely due to a rise in femaleincidence. A similar trend in the period 1940-71 has been confirmed at a national level in data abstracted from the Annual Reports of the Registrar General for Scotland.

The mean age at death has risen for both sexes. Aetiologically, the cirrhosis was alcoholic in음 $18.5 \%$, posticteric in $10.4 \%$, cryptogenic in $61.9 \%$, and haemochromatosis was diagnosed in $7.5 \%$. Primary malignant tumours of liver supervened in $12.3 \%$. The causes of death and the morphological patterns of the cirrhosis are reviewed.

The causes of cirrhosis of the liver are only partially understood and appear to vary considerably in different geographical areas. We had recently become convinced that there was an increasing incidence of cirrhosis cases coming to postmortem examination in this department. Consequently we have undertaken a clinico-pathological review of all cases of hepatic cirrhosis (excluding secondary biliary cirrhosis and so-called 'cardiac cirrhosis') coming to necropsy at the Western Infirmary, Glasgow, over the period 1900-69. The findings form the basis of this report. In addition the Annual Reports of the Registrar General for Scotland for the period 1940-71 have been examined and the recorded number of deaths from cirrhosis of the liver abstracted.

It seems to us that local surveys such as this, coming from hospitals with no special interest in hepatic disease, are of importance and may indicate changing trends in the disease pattern which may be of aetiological significance.

\section{Materials and Methods}

The clinical records and necropsy reports of 520 patients with hepatic cirrhosis (excluding secondary biliary and cardiac cirrhosis) at this hospital over the period 1900-69 (inclusive) have been reviewed.

Available postmortem material in 238 of these

'Present address: Victoria Infirmary, Glasgow.

Received for publication 21 August 1973. patients has been examined histologically, usieg $\vec{\oplus}$ routine staining methods: haematoxylin and eosin., $\omega$ Masson's trichrome, Gordon and Sweet's reticulin, Perls' iron, and the periodic acid-Schiff (PAS) method. The histological classification of the cirrhosis patterns was made without prior know-ڤ๊ ledge of the clinical history.

\section{Results}

CLINICO-PATHOLOGICAL REVIEW

The incidence of cirrhosis cases coming to necropsy for each decade of the period of study is given in? table I, together with the male/female distribution $\frac{\text { O }}{3}$ and the mean age at death. The age distribution is shown by histogram in figure 1 .

It is seen that there has been an increase in incidence of cirrhosis over the period 1950-69, this은 being particularly true for female cirrhotics where $D$ the incidence in 1940-49 (20/2914-0.7\%) has risen in $1960-69$ to $1 \cdot 3 \%(72 / 5630)$. The calculated incidencen per 1000 necropsies for males and females is. illustrated in figure 2 . The mean age at death has : risen for both sexes, for females notably in the 193039 decade and for males in the 1950-59 decade (table I). The number of female cases is small up tillo 1950-59 but if the mean ages at death for each sex over the period 1900-49 (males $48.7 \pm 14.5$ years? and females $47 \cdot 1 \pm 15 \cdot 0$ years) are compared with the corresponding mean age for each of the two decades 1950-59 and 1960-69 (table I), the results are 


\begin{tabular}{|c|c|c|c|c|c|c|c|}
\hline \multirow[t]{2}{*}{ Decade } & \multirow{2}{*}{$\begin{array}{l}\text { No. of } \\
\text { Necropsies }\end{array}$} & \multirow{2}{*}{$\begin{array}{l}\text { No. of Cases } \\
\text { of Cirrhosis } \\
\text { (\% of Necropsies) }\end{array}$} & \multicolumn{2}{|l|}{ Male } & \multirow[t]{2}{*}{ Female } & \multicolumn{2}{|c|}{ Mean Age $\pm 1 S D$} \\
\hline & & & & (Ratio) & & Male & Female \\
\hline $1900-09$ & 1857 & $38(2 \cdot 0)$ & 25 & \multirow{2}{*}{$\begin{array}{l}(2: 1) \\
(1 \cdot 5: 1)\end{array}$} & 13 & $44 \cdot 8 \pm 15 \cdot 7$ & $48 \cdot 3 \pm 15 \cdot 4$ \\
\hline $1910-19$ & 1540 & $35(2 \cdot 3)$ & 21 & & 14 & $49 \cdot 4 \pm 12 \cdot 8$ & $37 \cdot 7 \pm 14 \cdot 4$ \\
\hline $1920-29$ & 2264 & $46(2 \cdot 0)$ & 35 & \multirow{2}{*}{$\begin{array}{l}(3: 1) \\
(1 \cdot 8: 1)\end{array}$} & 11 & $46.9 \pm 12.6$ & $41 \cdot 8 \pm 15 \cdot 5$ \\
\hline $1930-39$ & 2609 & $48(1 \cdot 8)$ & 28 & & 20 & $50.6 \pm 13.8$ & $54 \cdot 0 \pm 12 \cdot 1$ \\
\hline $1940-49$ & 2914 & $61(2 \cdot 1)$ & 41 & \multirow{2}{*}{$\begin{array}{l}(2: 1) \\
(1 \cdot 3: 1)\end{array}$} & 20 & $50 \cdot 5 \pm 15 \cdot 1$ & $53 \cdot 2 \pm 12 \cdot 1$ \\
\hline $1950-59$ & 4751 & $128(2 \cdot 7)^{1}$ & 72 & & 55 & $57 \cdot 7 \pm 17 \cdot 4$ & $58 \cdot 2 \pm 15 \cdot 3$ \\
\hline $1960-69$ & 5630 & $164(2 \cdot 9)$ & 92 & $(1 \cdot 3: 1)$ & 72 & $60 \cdot 8 \pm 11 \cdot 1$ & $60 \cdot 1 \pm 13 \cdot 7$ \\
\hline Total & 21565 & $520(2 \cdot 4)^{1}$ & 314 & \multicolumn{2}{|l|}{$(1 \cdot 5: 1)$} & $55.4 \pm 15.9$ & $54 \cdot 5 \pm 16 \cdot 1$ \\
\hline
\end{tabular}

Table I Numbers of patients with cirrhosis coming to necropsy for each decade from 1900 to 1969 with male: female distribution and mean age at death

${ }^{1}$ One case with sex unrecorded

statistically significant $(P>0 \cdot 01$ for each comparison using a difference of means).

In table II possible aetiological factors based on the clinical records are summarized, and in table III the incidence of alcoholic and posticteric cirrhosis per decade is presented. It is seen that a history of alcoholism is three times as common in males as in females. In two patients there was a history both of alcoholic abuse and of a previous episode of jaundice suggestive of acute hepatitis. However, the degree of alcohol abuse was grossly excessive and

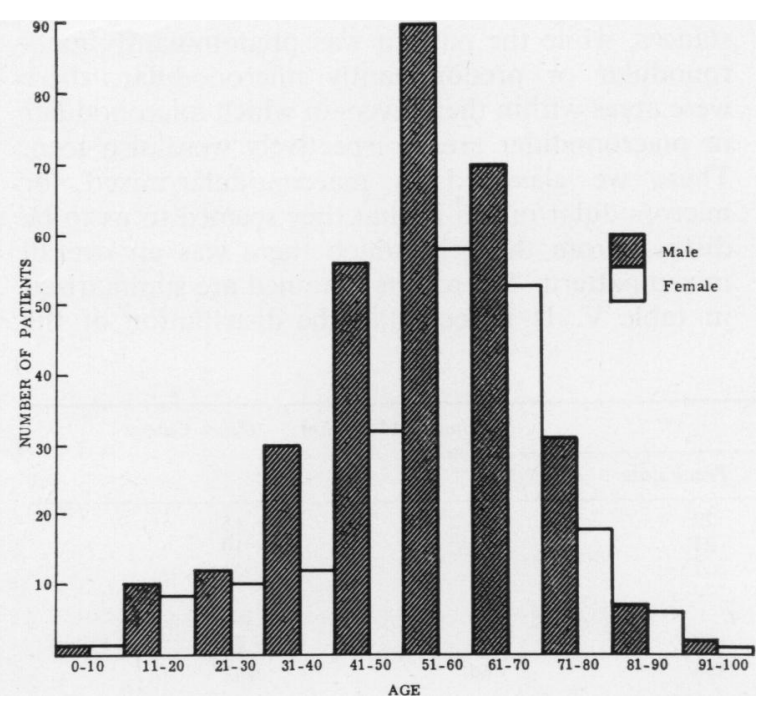

Fig 1 Histogram to show the age at death distribution in 520 patients with hepatic cirrhosis. they have been included in the alcoholic category. There is a striking but well recognized male predominance in haemochromatosis (13 to 1). The familial cirrhosis group comprises one male patient with Wilson's disease, and two female patients in whom the probable diagnosis was Wilson's disease, but with also a family history of galactosaemia (MacSween and Fell, 1973). The four cases of primary biliary cirrhosis have been diagnosed since 1966 , and it is probable that cases occurring before this were not diagnosed since the diagnostic value

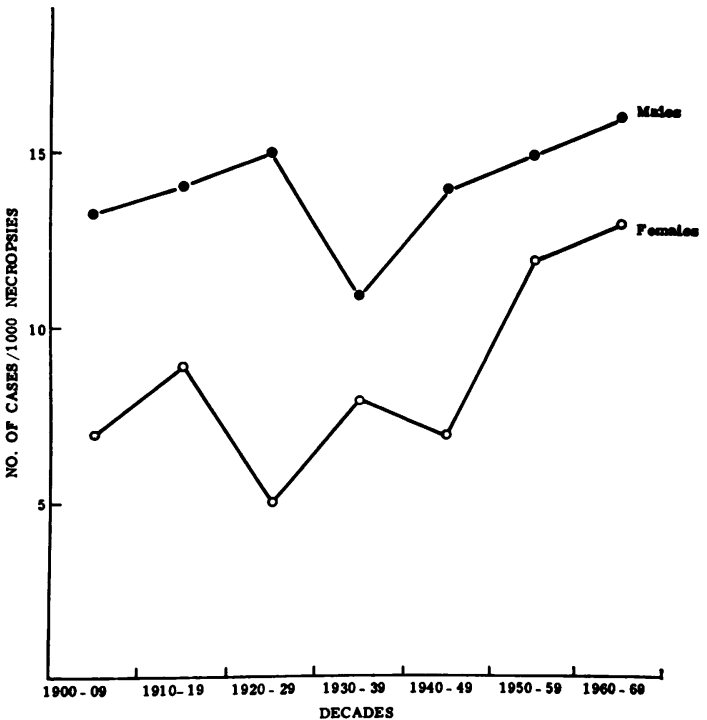

Fig 2 Male and female necropsy incidence of hepatic cirrhosis by decades, expressed per 1000 necropsies. 


\begin{tabular}{llll}
\hline Possible Aetiology & $\begin{array}{l}\text { Male } \\
\text { (\% of male } \\
\text { cirrhosis) }\end{array}$ & $\begin{array}{l}\text { Female } \\
\text { (\% of female } \\
\text { cirrhosis) }\end{array}$ & $\begin{array}{l}\text { Total } \\
(\% \text { of overall } \\
\text { total) }\end{array}$ \\
\hline Alcoholic & $79(25 \cdot 2)$ & $17(8 \cdot 3)$ & $96(18 \cdot 5)$ \\
Posticteric & $20(6 \cdot 4)$ & $34(16 \cdot 6)$ & $54(10 \cdot 4)$ \\
Haemochromatosis & $38(12 \cdot 1)$ & $3(1 \cdot 5)$ & $41(7 \cdot 9)$ \\
Familial & $1(0 \cdot 3)$ & $2(1 \cdot 0)$ & $3(0 \cdot 6)$ \\
Primary biliary & 0 & $4(2 \cdot 0)$ & $4(0 \cdot 8)$ \\
Cryptogenic & $176(56 \cdot 1)$ & $145(70 \cdot 7)$ & $322(61 \cdot 9)^{1}$ \\
Total & 314 & 205 & 520 \\
\hline
\end{tabular}

Table II Possible aetiological factors in male and female cirrhosis patients

${ }^{1}$ One case with sex unrecorded

\begin{tabular}{lccc}
\hline Decade & $\begin{array}{l}\text { No. of Cases } \\
\text { of Cirrhosis }\end{array}$ & $\begin{array}{l}\text { No. of Cases } \\
\text { of Alcoholic } \\
\text { Cirrhosis }\end{array}$ & $\begin{array}{l}\text { No. of Cases } \\
\text { Posticteric } \\
\text { Cirrhosis }\end{array}$ \\
\hline $1900-09$ & 38 & $10(26 \%)$ & 0 \\
$1910-19$ & 35 & $6(17 \%)$ & $1(3 \%)$ \\
$1920-29$ & 46 & $6(13 \%)$ & $4(9 \%)$ \\
$1930-39$ & 48 & $10(21 \%)$ & $10(21 \%)$ \\
$1940-49$ & 61 & $5(8 \%)$ & $10(16 \%)$ \\
$1950-59$ & 128 & $18(14 \%)$ & $14(11 \%)$ \\
$1960-69$ & 164 & $41(25 \%)$ & $15(9 \%)$ \\
Total & 520 & $96(18 \%)$ & $54(10 \%)$ \\
\hline
\end{tabular}

Table III Incidence of alcoholic and posticteric cirrhosis for each decade reviewed

of antimitochondrial antibody in this disease was not known before then.

The causes of death in these patients are summarized in table IV. Precipitate hepatic failure refers to patients in whom fatal gastrointestinal bleeding from oesophageal varices had occurred. In a number of instances, bleeding from varices had occurred in patients who also had a primary hepatic tumour in addition to cirrhosis, and when these are included the incidence of this complication in alcoholic, posticteric, haemochromatosis, and cryptogenic cases was $30 \cdot 2,39 \cdot 9,25 \cdot 0$, and $36.0 \%$ respectively. The corresponding figures for progressive hepatic failure in these subgroups were $44 \cdot 8,38 \cdot 9,12 \cdot 2$, and
$25.5 \%$ respectively. Excluding 10 haemochromatosis $\stackrel{0}{\vec{\sigma}}$ cases (nine with a syndrome of acute abdominal crisis. and fatal circulatory collapse (MacSween, 1966), and one with cardiac failure) in whom death was thus? attributable to their primary disease, it is seen that in 122 instances $(23.5 \%)$ death was attributable to $\overline{\bar{\omega}}$. other causes and cirrhosis was an incidental finding $\vec{\Phi}_{\overparen{D}}$ at postmortem examination.

Details of the 64 primary malignant liver tumours क are being published separately (MacSween, 1973). $\overrightarrow{0}$ This represents an overall $12.3 \%$ incidence of this complication supervening in cirrhosis. The corres- $\vec{\omega}$ ponding figures for males and females were $17.5 \frac{2}{2}$ and $4.4 \%$ respectively. The histological classification? of 52 of the 64 available for examination was hepato- $N$ cellular carcinoma (49), haemangioendothelial sar- $\vec{N}$ coma (2), and cholangiocarcinoma (1).

Other features of note: tuberculous peritonitis was recorded in six instances, and acute peritonitis in음 eight, but neither of these complications has beenrecorded since 1950. Extrahepatic primary tumours: were present in 25 patients; liver and other organ metastases were found in six, and in eight distant 3 metastases had occurred without there being hepatic involvement. Twenty-three patients had diabetes_ mellitus $(4.4 \%)$ and of these 11 had haemochro 8 matosis.

\section{HISTOLOGICAL REVIEW}

Postmortem liver tissue was available in 238 cases and an attempt was made to divide these intő macronodular, micronodular, and mixed patterns $\stackrel{\varnothing}{\varnothing}$ as defined by Scheuer (1968). However, it was found $\overrightarrow{\vec{F}}$ that this presented the difficulty that in some in-⿳亠丷厂 stances, while the pattern was predominantly mac-? ronodular or predominantly micronodular, thereo were areas within these livers in which micronodular or macronodular areas respectively were also seen? These we classified as macronodular/mixed, or micronodular/mixed in that they seemed to us to be distinct from those in which there was an overall mixed pattern. The results obtained are summarized in table V. It is seen that the distribution of thes

\begin{tabular}{|c|c|c|c|c|c|}
\hline & \multirow[t]{2}{*}{ Total No. } & \multicolumn{2}{|c|}{ Hepatic Failure } & \multirow{2}{*}{$\begin{array}{l}\text { Primary Malignant } \\
\text { Tumour }\end{array}$} & \multirow[t]{2}{*}{ Other Causes } \\
\hline & & Progressive & Precipitate & & \\
\hline $\begin{array}{l}\text { Alcoholic } \\
\text { Posticteric } \\
\text { Haemochromatosis } \\
\text { Familial } \\
\text { Primary biliary } \\
\text { Cryptogenic }\end{array}$ & $\begin{array}{r}96 \\
54 \\
41 \\
3 \\
4 \\
322\end{array}$ & $\begin{array}{r}43 \\
21 \\
5 \\
3 \\
3 \\
82\end{array}$ & $\begin{array}{r}29 \\
21 \\
7 \\
-1 \\
110\end{array}$ & $\begin{array}{r}9 \\
2 \\
9 \\
- \\
-\end{array}$ & $\begin{array}{l}15 \\
10 \\
21^{1} \\
- \\
\overline{86}\end{array}$ \\
\hline Total & 520 & 157 & 168 & 64 & 132 \\
\hline
\end{tabular}

Table IV Causes of death in 520 patients with cirrhosis subdivided according to possible aetiology

Includes nine cases of acute abdominal crisis with fatal circulatory collapse (MacSween, 1966), one of whom also had a primary hepatoma. 


\begin{tabular}{|c|c|c|c|c|c|c|}
\hline & Total No. & $\begin{array}{l}\text { Macronodular } \\
(\%)\end{array}$ & $\begin{array}{l}\text { Macronodular/ } \\
\text { Mixed } \\
(\%)\end{array}$ & $\begin{array}{l}\text { Micronodular } \\
(\%)\end{array}$ & $\begin{array}{l}\text { Micronodularl } \\
\text { Mixed } \\
(\%)\end{array}$ & $\begin{array}{l}\text { Mixed } \\
(\%)\end{array}$ \\
\hline $\begin{array}{l}\text { Male } \\
\text { Female }\end{array}$ & $\begin{array}{l}130 \\
108\end{array}$ & $\begin{array}{l}77(59 \cdot 2) \\
63(58 \cdot 3)\end{array}$ & $\begin{array}{l}14(10.8) \\
17(15 \cdot 7)\end{array}$ & $\begin{array}{c}14(10 \cdot 8) \\
8(7 \cdot 4)\end{array}$ & $\begin{array}{c}9(6 \cdot 9) \\
7(6 \cdot 5)\end{array}$ & $\begin{array}{c}16(12 \cdot 3) \\
13(12 \cdot 0)\end{array}$ \\
\hline Total & 238 & $140(58 \cdot 8)$ & $31(13.0)$ & $22(9 \cdot 2)$ & $16(6 \cdot 7)$ & $29(12 \cdot 2)$ \\
\hline $\begin{array}{l}\text { Male } \\
\text { Female }\end{array}$ & & \multicolumn{2}{|c|}{$\begin{array}{l}91(70 \cdot 0) \\
80(74 \cdot 1)\end{array}$} & \multicolumn{2}{|c|}{$\begin{array}{l}23(17 \cdot 7) \\
15(13 \cdot 9)\end{array}$} & \\
\hline Total & & \multicolumn{2}{|c|}{$171(71 \cdot 8)$} & \multicolumn{2}{|c|}{$38(16.0)$} & \\
\hline
\end{tabular}

Table V Distribution of cirrhosis patterns in male and female cirrhotic patients and in overall series

various patterns is similar for males and females. The macronodular pattern is by far the commonest, and when combined with the predominantly macronodular/mixed pattern, they comprised $71.8 \%$ of the livers examined.

The incidence of chronic continuing hepatitis was also assessed in these livers, based on the intensity of the chronic inflammatory cell infiltrate in portal areas and fibrous septae, the presence or absence of piecemeal necrosis, and the presence or absence of hepatitis within nodules. The findings are summarized in table VI and show that continuing activity is most frequently found in the mixed macronodular/ micronodular cirrhosis and in cirrhosis where macronodules predominate, whereas it is less common in the micronodular subgroups.

Postmortem liver sections were available from 43 of the 96 alcoholic cases, and the types of cirrhosis found in these were: macronodular or predominantly macronodular $28(65.1 \%)$; micronodular or predominantly micronodular $10(23.3 \%)$; mixed five
$(11.7 \%)$. Mallory's hyaline was present in $10(23 \%)$ and there was significant fatty infiltration in 11 (25\%).

Correspondingly in the posticteric group liver tissue was available from 33 of the 54 cases. The types of cirrhosis found were macronodular or predominantly macronodular $27(81.8 \%)$, micronodular four $(12 \cdot 1 \%)$, mixed two $(6 \cdot 1 \%)$. Mallory's hyaline was present in four livers, three of which had a micronodular cirrhosis, and in one of which there was a mixed pattern. In none of these four was there any history of alcohol abuse.

CIRRHOSIS DEATHS: REGISTRAR GENERAL'S RETURNS FOR SCOTLAND 1940-1971

The total number of male and female deaths in Scotland per five-year period for the years 1940-71 inclusive, and the corresponding number of deaths from cirrhosis are summarized in table VII. The male and female cirrhosis incidence expressed as number per 1000 deaths is illustrated in figure 3.

\begin{tabular}{lllllll}
\hline & Total No. & Macronodular & $\begin{array}{l}\text { Macronodularl } \\
\text { Mixed }\end{array}$ & Micronodular & $\begin{array}{l}\text { Macronodular/ } \\
\text { Mixed }\end{array}$ & Mixed \\
\hline Male & 130 & $24 / 77$ & $7 / 14$ & $2 / 14$ & $3 / 9$ & $9 / 16$ \\
Female & 108 & $23 / 63$ & $7 / 17$ & $1 / 8$ & $1 / 7$ & $8 / 13$ \\
Total & 238 & $47 / 140(33 \cdot 6 \%)$ & $14 / 31(45 \cdot 2 \%)$ & $3 / 22(13 \cdot 6 \%)$ & $4 / 16(25 \%)$ & $17 / 29(58 \cdot 6 \%)$ \\
\hline
\end{tabular}

Table VI Incidence of continuing hepatitis in the various types of cirrhosis

\begin{tabular}{|c|c|c|c|c|}
\hline \multirow[t]{2}{*}{ Period } & \multicolumn{2}{|c|}{ Total No. of Deaths } & \multicolumn{2}{|l|}{ Cirrhosis Deaths } \\
\hline & Male & Female & Male ( $\%$ of male deaths) & Female ( $\%$ of female deaths) \\
\hline $\begin{array}{l}1940-44 \\
1945-49 \\
1950-54 \\
1955-59 \\
1960-64 \\
1965-69 \\
1970-71\end{array}$ & $\begin{array}{r}176801 \\
161214 \\
158527 \\
158821 \\
163059 \\
160362 \\
64123\end{array}$ & $\begin{array}{r}164831 \\
156713 \\
153015 \\
150885 \\
152382 \\
152850 \\
61131\end{array}$ & $\begin{array}{l}456(0.26) \\
470(0.29) \\
489(0.31) \\
553(0.35) \\
692(0.42) \\
675(0.42) \\
242(0.38)\end{array}$ & $\begin{array}{l}254(0.15) \\
279(0.18) \\
361(0 \cdot 24) \\
504(0.33) \\
531(0 \cdot 35) \\
517(0.34) \\
216(0.35)\end{array}$ \\
\hline
\end{tabular}

Table VII Deaths from hepatic cirrhosis (1940-1971 inclusive) in Scotland as abstracted from the Annual Reports of the Registrar General

The figures are for the crude death rates. 


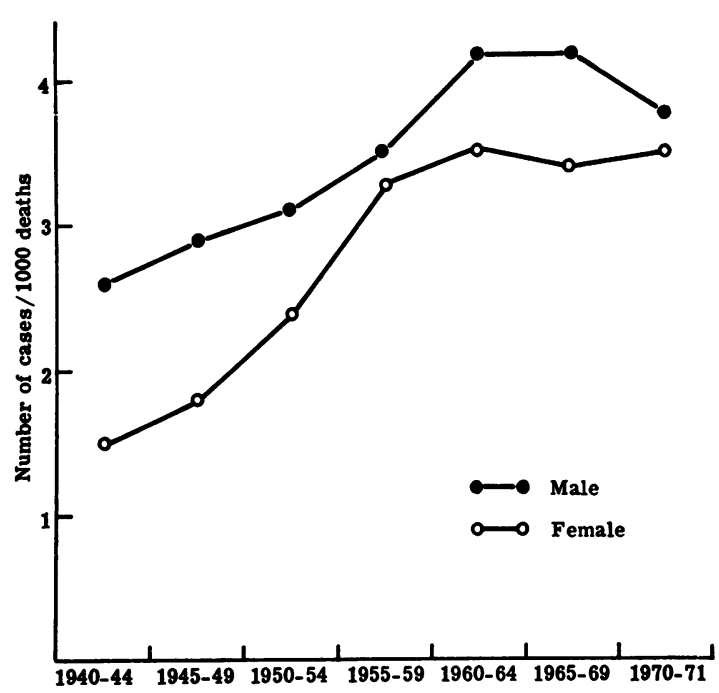

Fig 3 Male and female death rates from hepatic cirrhosis recorded in the mortality statistics of the Registrar General (Scotland) per five-year period from 1940 to 1971.

\section{Discussion}

Information regarding the frequency of cirrhosis in different parts of the world is difficult to cull from the vast literature on cirrhosis in general. MacDonald (1965) reviewed the incidence in different geographical areas, his information being obtained in part by questionnaires and in part by personal visits. He found the average necropsy frequency of cirrhosis in the USA to be $5.5 \%$, and in 23 countries $6 \cdot 1 \%$, with a range from $29.1 \%$ (France) to $0.6 \%$ (Ireland). His results from three Scottish hospitals (Glasgow, Aberdeen, and Edinburgh Royal Infirmaries) gave an average figure of $2.6 \%$ (range 1.1 to $3.6 \%$ ). Manderson, Patrick, and Peters (1968), in a review of primary carcinoma of the liver in the west of Scotland, reported a cirrhosis/necropsy incidence of $2.0 \%$ in this region. Our present figure of $2.4 \%$ is therefore in good agreement with these earlier observations.

There has been an increase in incidence of cirrhosis particularly in the period $1950-69$, the necropsy incidence being $2.8 \%$ for these 20 years as compared with $2.0 \%$ for the period $1900-49$. This increase is due largely to a rise in female incidence. Whereas over the periods 1900-49 and 1950-69 the calculated average number of male cases is 14 and 15.5 respectively per 1000 necropsies, the corresponding figures for female cases are 7.0 and 12.5 . There has been no overall increase in the number of females per 1000 necropsies performed, and in view of the $\frac{0}{5}$ observed differences in sex incidence it would seem 으 improbable that the increased cirrhosis incidence $\vec{F}$ is due to changes in patient care (such as a greater $\stackrel{?}{?}$ hospitalization rate).

The data abstracted from the Annual Reports of $\frac{\overline{\bar{O}}}{\overline{\mathrm{D}}}$ the Registrar General for Scotland from $1940 \frac{\bar{\sigma}}{\sigma}$ onwards (corresponding to the period in which $\cong$ changes were observed in the necropsy incidence of $\%$ cirrhosis) shows a continued steady rise in the $\overrightarrow{0}$ national figures for deaths from hepatic cirrhosis. If the crude death rates from cirrhosis for the five-year $\vec{\omega}$ periods 1940-44 and 1965-69 are compared there is an overall increase of $85 \%$, the corresponding? figures for males and females being 62 and $133 \%$ \% respectively. Thus the trends noted at a local level at $\vec{N}$ this hospital are reflected in a similar trend at a national level. The incidence of cirrhosis is increasing $\stackrel{\mathscr{\omega}}{\omega}$ and the rise is disproportionately greater in females. 을

Stone, Islam, and Paton (1968) drew attention to an increase in the crude death rate from cirrhosis in $\square$

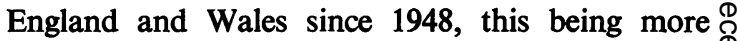
marked in women than in men. Schneiderbaur (1964) reported a considerable recent increase in cirrhosis in some European countries, particularly West Germany and Austria, both sexes being equall $\vec{\theta}$ affected. A similar increase in Switzerlane co (Schneiderbaur, 1964) seemed largely to be due to increase in alcoholic cirrhosis. Wadman, Spencer, and Werner (1971) found increases in incidence in Scandinavian countries, and in particular noted that in Denmark the increase was most marked in elderly females.

The reasons for the increasing female incidence in the present series is not readily apparent, and in particular there does not seem to have been an increase in alcoholic or posticteric cirrhosis in women. However, of interest in this context is the observation by Wilkinson, Santamaria, and Rankin $\frac{}{3}$ (1969) in Australia, that cirrhosis is twice as common in female alcoholics as in male alcoholics, and that $O$ cirrhosis was liable to develop in women after a shorter period of excessive drinking. Our findings $\frac{}{5}$ may therefore reflect fairly well recognized changes $D$ in female social and drinking habits over the past 20-30 years.

While the increase in the mean age at death during $ᄋ$ the most recent years is perhaps not surprising, the $N$ statistically significant size of the increase is striking. N MacDonald and Mallory (1958) noted a similar trend in their series in Boston. The increase may have ${ }_{0}$ resulted from better clinical care of the cirrhotic $\underset{\mathbb{D}}{\overparen{D}}$ patient since the advent of antibiotics and potent $\stackrel{\odot}{\rightarrow}$ diuretics and with improvement in the management $\square$ of hepatic failure. However, there is debate as to whether modern therapy has led to any considerable $\stackrel{\square}{\Omega}$ 
prolongation of survival in the majority of patients with cirrhosis. Some workers have found little evidence in support of this (Garceau and Chalmers, 1963; Creutzfeldt and Beck, 1966; Stone et al, 1968), whereas Powell and Klatskin (1968) in America and Powell, Mortimer, and Harris (1971) in Australia claimed that survival was significantly longer than that observed 30 years before. The increase in age may in part be a reflection of the general increase in life span. It is interesting to speculate that the incidence of cirrhosis may be higher in long-lived populations than in short-lived populations. Evidence in favour of this would depend on an assessment of any recent increase in the age at which patients present with cirrhosis, and it seems to us that such a prospective study is indicated.

In the present series classification of $62 \%$ of cases as cryptogenic cirrhosis is in agreement with Sherlock's (1971) finding that more than $50 \%$ of patients with cirrhosis in Great Britain fall into this category. In contrast to Sherlock's experience in London, cryptogenic cirrhosis was more common in females than in males. The high incidence of haemochromatosis in our necropsy material has been reported previously (MacSween and Jackson, 1966), and MacDorald (1965) has also drawn attention to the high incidence of haemochromatosis in Scotland. Parker (1967) and Stone et al (1968) reported incidences of haemochromatosis of 1.4 and $2.6 \%$ in their cirrhosis cases from London and Birmingham respectively, whereas Sherlock (1971), admittedly in a probably highly selected group of 561 cirrhotics, found haemochromatosis in 29 $(5 \cdot 2 \%)$.

The incidence of alcoholism (25.2\%) in our series is similar to that of Sherlock (1971), but shows a more marked male preponderance. Stone et al (1968) found a $33.5 \%$ alcoholic incidence in Birmingham. These figures, however, are still considerably lower than those reported from other geographical areas, notably the $83 \%$ incidence found in Boston (Garceau and Chalmers, 1963). There seems little doubt now but that alcohol has a direct toxic action on the liver (Lieber and Rubin, 1968; Rubin and Lieber, 1968). Nevertheless only a small percentage of alcoholics develop chronic liver disease (Voegtlin, Broz, and Moss, 1949; Sherlock, 1971), and there are clearly other factors of importance in determining the progression to cirrhosis, among which viral hepatitis has again been recently implicated (Pettigrew, Goudie, Russell, and Chaudhuri, 1972).

Progressive hepatic failure was commoner in alcoholic cirrhosis, whereas failure precipitated by bleeding from oesophageal varices was commoner in the cryptogenic group. The incidence of hepatic neoplasia supervening in cirrhosis was $12.3 \%$, but with a striking difference between males $(17 \cdot 3 \%)$ and females (4.5\%) (MacSween, 1973). The high incidence of tumour developing in haemochromatosis cases $(23.2 \%)$ is most appropriately compared with the male incidence, in that 38 of the 41 patients were male, and is then not statistically significant. Tumour supervened in $9.6 \%$ of alcoholic cirrhosis cases and this is higher than the figure of about $5 \%$ noted by Sherlock (1971).

The histological revicw of our material emphasizes that the end-stage pattern of cirrhosis is most commonly macronodular. Whereas Scheuer (1968) divided cirrhosis into three morphological varietiesmacronodular, micronodular, and mixed-we found this classification difficult to apply. We were impressed by a number of cases in which, although the pattern was predominantly macronodular or micronodular, there were focal areas in which the pattern was mixed, in contrast to the overall admixture seen in the mixed category. It is not clear whether these two additional categories represent livers in which there is a progressive change from an earlier micronodular to a macronodular pattern. It is of interest, however (table VI), that the occurrence of continuing hepatitis was much more frequent in the macronodular or mixed varieties, as compared with the pure micronodular group, suggesting that it was this process of continuing parenchymal destruction which eventually produced the macronodular pattern.

We were unable to show any good correlation between the possible aetiological factors and histological classification. Of particular note was the finding that in $65.1 \%$ of cirrhosis in alcoholics the final histological pattern was macronodular, emphasizing the observations of Rubin, Krus, and Popper (1962) that with necrosis and collapse developing, the micronodular or so-called 'nutritional' cirrhosis progresses to resemble that seen in end-stage liver disease from various causes.

We found no evidence to support the assertion that diabetes is more common in cirrhosis. While the number of cases in the present series is small it would appear that hepatic metastases from other organs is not an uncommon occurrence in cirrhosis.

We are grateful to the staff of the Records Office, Western Infirmary, Glasgow, for making available the clinical records in the cases studied.

\section{References}

Creutzfeldt, W., and Beck, K. (1966). Cirrhosis of the liver. On the aetiology, pathogenesis, results of treatment and period of survival in an unselected series of 560 patients. Germ. med. Mth, 11, 259-265.

Garceau, A. J., Chalmers, T. C., and The Boston Inter-Hospital Liver Group (1963). The natural history of cirrhosis. 1. Survival witb esophageal varices. New Engl. J. Med., 268, 469-473. 
Lieber, C. S., and Rubin, E. (1968). Alcoholic fatty liver in man on a high protein and low-fat diet. Amer. J. Med., 44, 200-206.

MacDonald, R. A. (1965). Hemochromatosis and cirrhosis in different geographic areas. Amer. J. med. Sci., 249, 36-46.

MacDonald, R. A., and Mallory, G. K. (1958). The natural history of postnecrotic cirrhosis. Amer. J. Med., 24, 334-357.

MacSween, R. N. M. (1966). Acute abdominal crisis, circulatory collapse and sudden death in haemochromatosis. Quart. J. Med., ns, 35, 589-598.

MacSween, R. N. M. (1973). Primary malignant tumours of the liver: a clinico-pathological review of 100 cases. (In preparation.)

MacSween, R. N. M., and Fell, G. S. (1973). Familial cirrhosis. Scot. med. J., in press.

MacSween, R. N. M., and Jackson, J. M. (1966). Haemochromatosis: A clinico-pathological review of 37 cases. Scot. med. J., 11, $395-400$.

Manderson, W. G., Patrick, R. S., and Peters, E. E. (1968). Incidence of primary carcinoma of the liver in the West of Scotland between 1949 and 1965 . Gut, 9, 480-484.

Parker, R. G. F. (1957). The incidence of primary hepatic carcinoma in cirrhosis. Proc. roy. Soc. Med., 50, 145-147.

Pettigrew, N. M., Goudie, R. B., Russell, R. I., and Chaudhuri, A. K. R. (1972). Evidence for a role of hepatitis virus B in chronic alcoholic liver disease. Lancet, 2, 724-725.

Powell, L. W., Mortimer, R., and Harris, O.D. (1971). Cirrhosis of the liver. A comparative study of the four major aetiological groups. Med. J. Aust., 1, 941-950.
Powell, W. J., Jr., and Klatskin, G. (1968). Duration of survival in $\stackrel{0}{=}$ patients with Laěnnec's cirrhosis. Amer. J. Med., 44, 406-420. 으

Registrar General for Scotland Annual Reports (1940-72). Nos. 86-117 (inclusive). HMSO, Edinburgh.

Rubin, E., Krus, S., and Popper, H. (1962). Pathogenesis of postne- $\mathscr{O}$ crotic cirrhosis in alcoholics. Arch. Path., 73, 288-299.

Rubin, E., and Lieber, C. S. (1968). Alcohol-induced hepatic injury in nonalcoholic volunteers. New Engl. J. Med., 278, 869-876.

Scheuer, P. J. (1968). Liver Biopsy Interpretation, p. 55. Bailliere, Tindall and Cassell, London.

Schneiderbaur, A. (1964). Zur Frage der Häufigkeit, der Zunahme $ᄋ$ und der Äetiologie der Leberzirrhose. Wien. med. Wschr., 114, ڤ) 738-747.

Sherlock, S. (1971). Diseases of the Liver and Biliary System, 4th ed., $\vec{\circ}$ revised 3rd printing. Blackwell, Oxford.

Stone, W. D., Islam, N. R. K., and Paton, A. (1968). The natural history of cirrhosis. Quart. J. Med., n.s., 37, 119-132.

Voegtlin, W. L., Broz, W. R., and Moss, M. H. (1949). Liver function in chronic alcoholic patients. 1 . The incidence of liver disease as indicated by laboratory methods and suggested screening procedure. Gastroenterology, 12, 184-198.

Wadman, B., Spencer, E. S., and Werner, I. (1971). Liver cirrhosis in three Scandinavian communities. Acta med. scand., 189, $\overrightarrow{\mathrm{N}}$ 221-230.

Wilkinson, P., Santamaria, J. N., and Rankin, J. G. (1969). Epidemiology of alcoholic cirrhosis. Aust. Ann. Med., 18, 222-226. 